\title{
Perbaikan Adaptasi Tanaman Gandum (Triticum aestivum L.) di Dataran Rendah Melalui Mutasi Induksi
}

\section{The Improvement of Wheat Adaptations in Low Land by Induced Mutation}

\author{
Rati Riyati \\ UPN"Veteran" Yogyakarta \\ Jln. Lingkar Utara SWK 104 Yogyakarta \\ E-mail:rati_riyati@yahoo.co.uk
}

\begin{abstract}
The research was carried out to increase the wheat genetic variability by mutation technic using Gama Rays Cobalt-60, and to find out wheat variety which had adaptation on low land. The research had been done at Experimental Station of Gajah Mada University at Banguntapan, Bantul Daerah Istimewa Yogyakarta. The field experiment was arranged on Randomized Complete Block Design with two factors and three replications. The first factor was the dosage of irradiation gamma rays Cobalt-60 i.e.: D0=no irradiations, D1=20 Krad, and D2=30 Krad. The second factor was the variety of M3 wheat seed i.e.V1=WL-2265, V2=SA-75, V3=DWR 195, and V4=PN-81. The result showed that the genetic variability of WL-2265, Sa-75, DWR 195, and PN 81 had increased by irradiation Gamma rays Cobalt-60. WL-2265 and DWR-195 which were irradiated by Gamma rays Cobalt-60 at 20 and $30 \mathrm{Krad}$ had given better growth and yield in low land than their parents.
\end{abstract}

Keywords: Irradiation, Gamma rays, induceced mutation, wheat variety

\begin{abstract}
Abstrak
Penelitian bertujuan meningkatkan keragamanan genetik tanaman gandum di Indonesia melalui teknik mutasi menggunakan sinar gamma dari Cobalt-60, dan menemukan galur gandum yang dapat dibudidayakan di dataran rendah. Penelitian lapangan dilaksanakan di Kebun Percobaan Universitas Gadjah Mada, Kecamatan Banguntapan, Bantul, Daerah Istimewa Yogyakarta pada ketinggian $\pm 150 \mathrm{~m}$ dpl. Rancangan percobaan yang digunakan adalah Rancangan Acak Kelompok Lengkap (RAKL) dengan 2 faktor. Faktor I adalah iradiasi sinar gamma yang terdiri atas 3 aras, yaitu $D_{0}$ : Tanpa perlakuan iradiasi, $D_{1}$ : iradiasi $20 \mathrm{Krad}$, dan $D_{2}$ : iradiasi 30 Krad. Faktor II adalah tanaman $M_{3}$ yang terdiri atas 4 aras, yaitu: V1=WL2265, V2=SA-75, V3=DWR -195, dan V4=PN-81. Dari hasil penelitian dapat disimpulkan bahwa perlakuan iradiasi sinar gamma dengan Cobalt-60 dapat meningkatkan keragaman genetik tanaman gandum di Indonesia dengan tetua WL-2265, SA-75, DWR-195, dan PN-81, sehingga dapat digunakan sebagai sumber genetik baru dalam program hibridisasi. Varietas WL-2265 dan DWR-195 yang diberi perlakuan iradiasi sinar gamma Cobalt-60 dengan dosis 20 krad maupun 30 krad dapat menghasilkan galur gandum yang mampu tumbuh di dataran rendah dengan hasil yang lebih baik daripada tanaman tetuanya.
\end{abstract}

Kata kunci: Sinar gamma, mutasi, varietas gandum 